\title{
Design of Operational Strategy with Variable-Costing-Based Menu Engineering Information System for Restaurants in Surabaya
}

\author{
Ardhian Heru Saputra ${ }^{1 *}$, Supangat ${ }^{2}$ \\ ${ }^{1}$ Program Studi Management, Universitas Airlangga, Surabaya, Indonesia \\ ${ }^{2}$ Program Studi Teknik Informatika, Universitas 17 Agustus 1945, Surabaya, Indonesia \\ *Corresponding author email: ardhian.heru.saputra-2018@feb.unair.ac.id
}

\begin{abstract}
Restaurant management is always trying to sell a menu that has a high level of sales with a high level of profit as well. Actually, there tends to be a difference in the level of popularity and the level of profit contribution from each menu. The level of popularity is determined by the percentage of sales of the menu compared to total sales, while the level of profit contribution is calculated by the variable costing method. Variable costing is the determination of the cost of production, which only charges variable production costs into the cost of the product. The cost of the product, according to the variable costing method, consists of the cost of raw materials, variable labor costs, and variable restaurant overhead costs. The research was carried out with a case study in a Chinese food restaurant in Surabaya with a monthly turnover of Rp180,000,000.00 to Rp 200,000,000.00. The research was intended to determine the operational and marketing strategies of each menu through an information system created based on the calculation of variable costing and popularity. The author conducted a field study, namely by collecting data directly from the restaurant with the method of observation and interviews with management. The author uses the information system as a means of determining the mapping of each menu to be classified into 4 clusters: Star, Plow horse, Puzzle, and Dog. From this mapping, there were five menus classified as Star, ten menus classified as Plow horse, 13 menus classified as Puzzle, and seven menus classified as Dog. The results of the mapping provide marketing and operational strategy recommendations for each menu at the restaurant
\end{abstract}

Keywords: restaurant, menu engineering, variable costing, information systems.

\section{INTRODUCTION}

The culinary world is developing rapidly in Indonesia, especially in urban areas. The development of the cafe and restaurant sector business in the east of Java alone is estimated to grow by $20 \%$ in 2019[1]. With the increasingly fierce culinary business competition, forcing restaurants to use information technology that is able to support work activities quickly and accurately. Information technology plays an important role in handling business today because of the need for an automated system so that businesses run faster, have more accurate calculations, and can support decisions that are right on target, especially in data collection about the popularity and cost of a menu.

In calculating costs, the variable costing approach, known as contribution approach, is an income statement format that groups costs based on cost behavior where costs are separated according to variable cost categories and fixed costs and are not separated according to production, administration, and sales functions. Variable costing has several advantages, including: can be used as 
an operational planning tool, determining the selling price, determining the break-even point or the return point of principal, and management control tools.

Reports that are registered with the variable cost are far more effective than full costing for management control. This is because these reports can be linked more directly to profit targets or budgets in the relevant period. Deviations from specified standards can be more easily identified and corrected more quickly. In addition to that the variable costing can be clearly demonstrated responsibility in accordance with the organizational line, individual pretensions can be evaluated from the current period.

Based on this understanding, in this study, the author wants to create a sales information system that helps the sales process at a place to eat while setting the cost of goods sold using variable costing to get more accurate results.

\subsection{Related Work}

Some of the research that participated as references in this study include:

\section{INFORMATION SYSTEM}

Broadly speaking, an information system is a system created to provide information in decision making for management and in the context of carrying out organized operations and procedures. as for some understanding of information systems according to experts as follows:

- Alter believes that information systems are a combination of procedures, work, information, people which is organized to achieve goals in an organization [2].

- Gelinas, Orams, and Wiggin argue that an information system is a man-made system that generally consists of a set of computer-based components and manuals that are created to collect, store and manage data and provide information output to users [2].

- Turban, McLean, and Waterbed argue that information systems are systems that collect, process, store, analyze, and disseminate information for specific purposes [2].

- Joseph Wilkinson argues that the information system is a framework that coordinates resources (human, computer) to transform input or output into an output that is the information intended to achieve organizational goals [2].

\section{VARIABLE COSTING}

Variable costing is the determination of the cost of production, which only charges variable production costs into the cost of the product. The cost of the product according to the variable costing method consists of the cost of raw materials, variable labor costs, variable factory overhead costs [3]

Raw material costs

Rp. Xxx.
Variable labor costs

Rp. Xxx

Variable factory overhead costs Rp. Xxx.

Cost of Production

Total Cost

Rp. $X x x+$.

Rp. XxX

Variable costing is commonly referred to as direct costing, the term direct costing is not related to the term direct cost (direct cost). Understanding whether or not a direct cost depends on whether or not the cost related to the object of cost determination, for example, product, process, department, and other cost centers, in relation to direct cost products [3].

\section{MENU ENGINEERING}

The definition of menu engineering is stated in the book "Computer Systems for Food Service Operations" Michael L. Kasavana cites the function of menu engineering, namely: "menu engineering is a service process through which management can evaluate the current and pricing of menus, designs, and future content ".[4]

From the above resolutions, can be deduced from the menu analysis as a management aid to make and decision in the price, design and contents of the menu for both current and future.

Basically, this menu analysis must discuss each menu item offered to guests. This effectiveness supports the level of popularity and the level of benefits derived from each food (menu item). The results of this analysis are expected to help the management in preparing the menu requested by guests and profitable so that sales targets can be obtained. In the same book, Michael L. Kasavana cites the analysis menu based on two things:[4]

1. Menu Mix (MM) is an analysis of the guests' fondness for food choices in the menu (analysis of the popularity level of each type of food)

2. Contribution Margin (CM) is an analysis of the finances of all types of food on the menu.

After calculating MM\% \& CM, we classify menu items based on the MM\% category and CM category.

The classifications are

1. Dog (MM\% low, low CM),

2. Puzzle (MM\% low, CM high),

3. Plowhorse (MM\% high, CM low),

4. Star (MM\% and high CM).

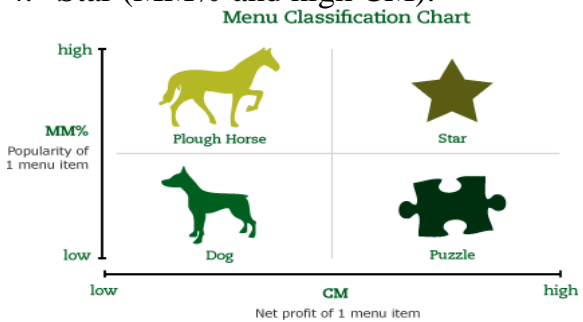

Figure 1 Menu Classification chart based on popularity and Margin

\subsection{Our Contribution}

This paper will present ways to identify menus that 
have low popularity or low profits. The information system will accelerate the identification of these problems in each accounting period. In addition, with variable costing combined with information systems, the data obtained will be more accurate for management policies, both operational and marketing for each menu.

\subsection{Paper Structure}

The rest of this paper is organized as follows. Section 2 introduces the introduction used in this paper, which tells the situation of the restaurant and the problems encountered. Then, the calculation pattern is entered into the information system in section 3 . And section 4 is a conclusion.

\section{PROBLEMS AND SOLUTIONS}

\subsection{Menu Engineering Process}

The authors use the Chinese food restaurant data in Surabaya with a monthly turnover of 180,000,000200,000,000 Rupiahs. From research conducted from January 1, 2020 - February 1, 2020, restaurant sales only reached Rp.173,592,000. This is certainly below the average rating of the restaurant. For this reason, Menu Engineering analysis is needed to be able to know the potential and follow-up actions that must be taken to meet the specified targets.

The twelve menu engineering steps are then performed as follows:[4]

Stage 1: Identifying competing menu ingredients.

Stage 2: Record the amount of material sold (used)

$$
M M=\frac{\text { menu items sold }}{\text { the amount of total items sold }}
$$

Stage 3: Calculate the proportion of mixed menu ingredients. Each sale is divided according to the total number of covers sold which results in a mixed menu Stage 4: Categorize the percentage of mixed menus (MM\%). The high or low category depends on the MM\% value obtained. Achievement is determined by adding $80 \% \times 1$ divided by the number of competing menus (1/ $\mathrm{N})$. The result can be:

$$
\begin{aligned}
& \text { (a) MM\% value }=\frac{100 \%}{\text { number items }} 0.8, \text { means high } \\
& \text { (b) MM\% value }>\frac{\text { number items }}{100 \% \text {, means low }} 0.8 \\
& \text { (c) MM\% value }<\frac{\text { number items }}{100 \%}
\end{aligned}
$$

Stage 5: Make a list of menus selling prices.

Stage 6: Determine standard food prices, sum up the prices of all ingredients used.

Stage 7: Calculate the contribution of menu item margins. Margin contributions for each ingredient are obtained by reducing the selling price (Stage 5) with the standard cost of food ingredients (Stage 4).

$\mathrm{CM}=$ Selling Price - Standard Food Cost

Stage 8: Determine the Margin Contribution (CM) menu. The amount of each CM menu item (Stage 7), multiplied by MM (Stage 2) to determine the total CM menu

Stage 9: Calculate the proportion of material contributed to the margin. Each CM material (Stage 7) is divided by the CM menu (Stage 8) to produce CM\% menu material (Percentage of Margin Contributions)

$$
\mathrm{CM} \%={ }^{\text {menu's margin }}
$$

Stage 10: Classify contribution margin materials. The high or low classification depends on whether it exceeds the average $\mathrm{CM}$ value. The value is calculated by dividing the CM menu (Stage 8) by the total amount of material sold (Stage 2). The result can be:

(a) $\quad \mathrm{CM} \%=\mathrm{CM}$ value

(b) $\quad \mathrm{CM} \%>\mathrm{CM}$ value, means high

(c) $\quad \mathrm{CM} \%<\mathrm{CM}$ value, means low

Stage 11: Applying the classifications of MM\% category menu items (Stage 4) and CM categories (Stage 10), used to assign menu categories to specific classes.

Stage 12: Propose a decision to maintain, reposition, replace or rearrange the price of menu items

In the research process, there were 35 menus that were assessed for the level of sales and profitability. 35 The menu is divided into 21 Foods \& snacks and 14 beverages. Cost calculation follows Variable Costing, so the calculated cost includes Food Cost, Labor Cost, and overhead cost.

We take Aglio Olio' as an example. First, we assign the popularity category through stages 1 to 4 . Aglio Olio Menu Mix is 83. After that, look for the percentage of each menu mix, with the formula MM\% = Menu mix divided by Total Menu Mix times 100\%. MM\% Aglio Olio $=83 / 3568 \times 100 \%=2.33 \%$. The next stage is to determine the mixed menu category by finding the average mix menu. The formula is $100 \%$ / the number of menus $\times 80 \%$ x $100=3.8 \%$. In conclusion, the $\mathrm{MM}$ category of Aglio Olio is $2.33 \%$, lower than $3.8 \%$.

Secondly, we define the Contribution Margin category. Aglio Olio has selling price Rp.50,000/dish, and the cost takes Rp.35,000/dish. So the margin is Rp.15,000/dish. On the other hand, the total margin divided by the amount of order is Rp.13,674.83. It means the Aglio Olio's margin is higher than the average. Since the MM\% is low and CM is high, Aglio Olio is categorized into Puzzle. Since then, Aglio Olio need a 
better marketing strategy

Table 1 Menu Classification Result

\begin{tabular}{|c|c|c|c|c|c|c|c|c|}
\hline $\begin{array}{c}\text { Menu ltem Name } \\
\text { Main Course \& Snack }\end{array}$ & $\begin{array}{l}\text { Number } \\
\text { Sold }\end{array}$ & Popularity \% & $\begin{array}{l}\text { Popularity } \\
\text { Category }\end{array}$ & $\begin{array}{c}\text { Item Food } \\
\text { Cost }\end{array}$ & $\begin{array}{l}\text { Item Sell } \\
\text { Price }\end{array}$ & $\begin{array}{c}\text { Item Profit } \\
\text { (E-D) }\end{array}$ & $\begin{array}{c}\text { Profit } \\
\text { Category }\end{array}$ & $\begin{array}{l}\text { Menu ltem } \\
\text { Class }\end{array}$ \\
\hline 1 Indomie Goreng / kuah & 152 & $4.26 \%$ & High & 4,000 & 12,000 & 8,000 & Low & Plowhorse \\
\hline 2 Indomie Special & 221 & $6.19 \%$ & High & 17,500 & 25,000 & 7,500 & Low & Plowhorse \\
\hline 3 Oglio Olio & 83 & $2.33 \%$ & Low & 35,000 & 50,000 & 15,000 & High & Puzzle \\
\hline$4 \longdiv { \text { Pork Mee } }$ & 192 & $5.38 \%$ & High & 32,000 & 45,000 & 13,000 & Low & Plowhorse \\
\hline 5 Pasta & 79 & $2.21 \%$ & Low & 35,000 & 50,000 & 15,000 & High & Puzzle \\
\hline 6 Sate babi & 301 & $8.44 \%$ & High & 20,000 & 50,000 & 30,000 & High & Star \\
\hline$7 \longdiv { \text { Rice Bowl Pork salted egg } }$ & 201 & $5.63 \%$ & High & 33,000 & 45,000 & 12,000 & Low & Plowhorse \\
\hline 8 Rice Bowl Pork Original & 265 & $7.43 \%$ & High & 28,000 & 45,000 & 17,000 & High & Star \\
\hline 9 Rice Bowl Pork caramilized & 330 & $9.25 \%$ & High & 33,000 & 45,000 & 12,000 & Low & Plowhorse \\
\hline 10 Rice Bowl Crispy Chicken & 275 & $7.71 \%$ & High & 28,000 & 45,000 & 17,000 & High & Star \\
\hline$1 1 \longdiv { \text { Rice Bowl Crispy Dory } }$ & 120 & $3.36 \%$ & Low & 28,000 & 45,000 & 17,000 & High & Puzzle \\
\hline 12 Iga Babi penyet & 54 & $1.51 \%$ & Low & 40,000 & 50,000 & 10,000 & Low & Dog \\
\hline 13 French Fries & 130 & $3.64 \%$ & Low & 8,000 & 20,000 & 12,000 & Low & Dog \\
\hline 14 Toasted Bread & 93 & $2.61 \%$ & Low & 5,000 & 12,000 & 7,000 & Low & Dog \\
\hline 15 Krupuk & 123 & $3.45 \%$ & Low & 1,000 & 2,000 & 1,000 & Low & Dog \\
\hline 16 Strips nugget & 150 & $4.20 \%$ & High & 20,000 & 28,000 & 8,000 & Low & Plowhorse \\
\hline 17 Soto ayam & 423 & $11.86 \%$ & High & 18,900 & 27,000 & 8,100 & Low & Plowhorse \\
\hline 18 Baikut Sayur Asin & 110 & $3.08 \%$ & Low & 20,000 & 40,000 & 20,000 & High & $\begin{array}{l}\text { Puzzle } \\
\end{array}$ \\
\hline 19 Pork Geprek & 71 & $1.99 \%$ & Low & 25,000 & 45,000 & 20,000 & High & Puzzle \\
\hline 20 Ayam Geprek & 65 & $1.82 \%$ & Low & 30,000 & 40,000 & 10,000 & Low & Dog \\
\hline 21 Nasi goreng & 130 & $3.64 \%$ & Low & 20,000 & 40,000 & 20,000 & High & Puzzle \\
\hline
\end{tabular}

\begin{tabular}{|c|c|c|c|c|c|c|c|c|}
\hline $\begin{array}{c}\text { Menu Item Name } \\
\text { Beverage }\end{array}$ & $\begin{array}{c}\text { Number } \\
\text { Sold }\end{array}$ & $\begin{array}{c}\text { Popularity } \\
\%\end{array}$ & $\begin{array}{l}\text { Popularity } \\
\text { Category }\end{array}$ & $\begin{array}{l}\text { Item Food } \\
\text { Cost }\end{array}$ & $\begin{array}{l}\text { Item Sell } \\
\text { Price }\end{array}$ & $\begin{array}{l}\text { Item Profit } \\
\text { (E-D) }\end{array}$ & $\begin{array}{c}\text { Profit } \\
\text { Category }\end{array}$ & $\begin{array}{l}\text { Menu Item } \\
\text { Class }\end{array}$ \\
\hline$1 \longdiv { \mathrm { Tea } }$ & 510 & $29.1 \%$ & High & 3,000 & 9,000 & 6,000 & Low & Plowhorse \\
\hline 2 Lemon Tea & 76 & $4.3 \%$ & Low & 8,000 & 20,000 & 12,000 & High & Puzzle \\
\hline 3 Mango Tea & 22 & $1.3 \%$ & Low & 10,000 & 20,000 & 10,000 & Low & Dog \\
\hline 4 Lrchee tea & 42 & $2.4 \%$ & Low & 8,000 & 25,000 & 17,000 & High & Puzzle \\
\hline 5 Orange & 50 & $2.9 \%$ & Low & 13,000 & 30,000 & 17,000 & High & Puzzle \\
\hline 6 Juice & 78 & $4.5 \%$ & Low & 13,000 & 30,000 & 17,000 & High & Puzzle \\
\hline 7 Moctail & 27 & $1.5 \%$ & Low & 20,000 & 35,000 & 15,000 & High & Puzzle \\
\hline 8 Bir Bintang & 333 & $19.0 \%$ & High & 30,000 & 45,000 & 15,000 & High & Star \\
\hline 9 Guiness & 106 & $6.1 \%$ & High & 32,000 & 40,000 & 8,000 & Low & Plowhorse \\
\hline 10 Bali Hai & 94 & $5.4 \%$ & Low & 20,000 & 35,000 & 15,000 & High & Puzzle \\
\hline 11 Healthy DrinkCan & 62 & $3.5 \%$ & Low & 10,000 & 20,000 & 10,000 & Low & Dog \\
\hline 12 Cappucino & 133 & $7.6 \%$ & High & 12,000 & 20,000 & 8,000 & Low & Plowhorse \\
\hline 13 Coffee Lattee & 72 & $4.1 \%$ & Low & 7,000 & 20,000 & 13,000 & High & Puzzle \\
\hline 14 Ekspresso & 147 & $8.4 \%$ & High & 5,000 & 20,000 & 15,000 & High & Star \\
\hline
\end{tabular}

As Aglio Olio's calculation, the other menu has the same treatment. The result mentioned that we have five menus classified as Star, ten menus classified as Plow horse, 13 menus classified as Puzzle, and seven menus classified as Dog.

\section{Information System for Menu Engineering}

The process of calculating and determining the menu's category is mentioned in the flowchart, as in Figure 2 below. This logic is inputted into an information system.

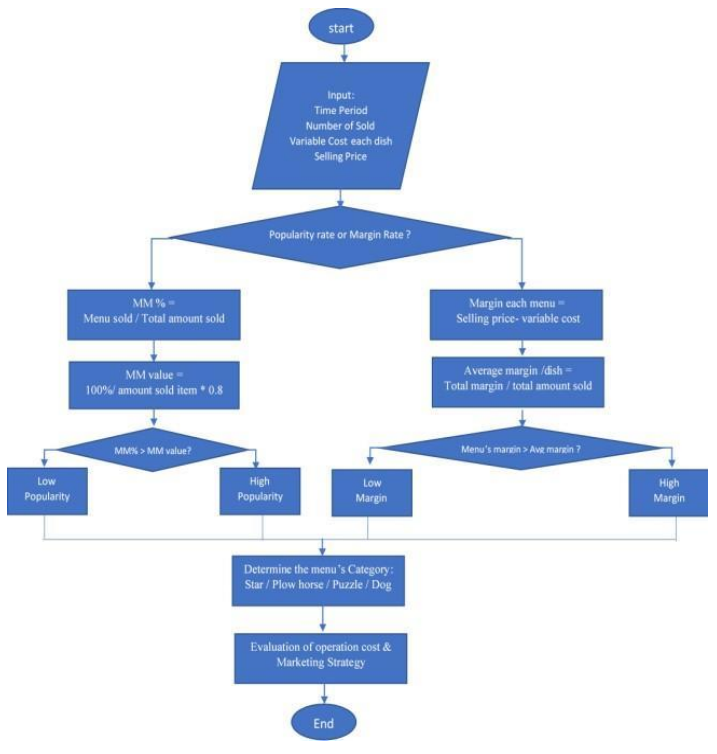

Figure 2 Flowchart of Information system's logic

We make the system for the owner of a restaurant by the flowchart in Figure 2. Thus the system is made to suit the design of already created and approved systems. Then the final step is the application of the system design that has been made. To applicate this system, the owner needs input and output interface. The following step will be the interface for the owner.

\subsubsection{LOGIN PROCESS}

In this module, the owner logs in using the username and password that was created.

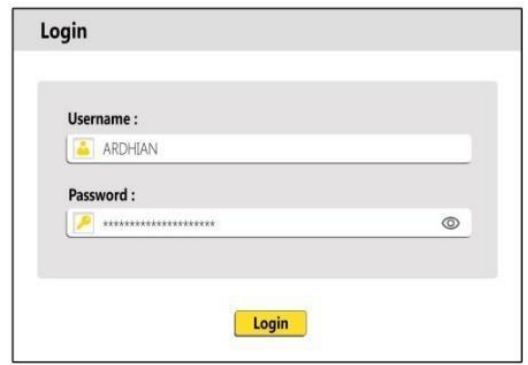

Figure 3 Interface of Login Process

After the user login, user can choose one process that he wants to input 


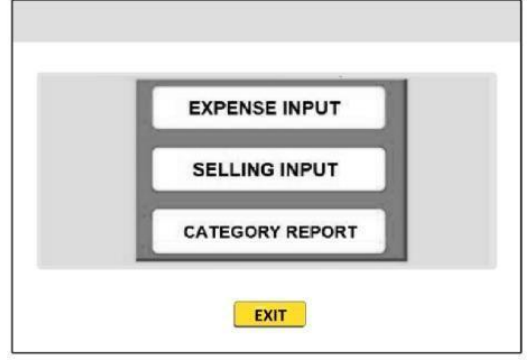

Figure 4 Interface of the Choosing process

\subsubsection{EXPENSE INPUT}

In this module, the cost data input process will be carried out, both foodstuffs, overhead, employee salaries, and others.

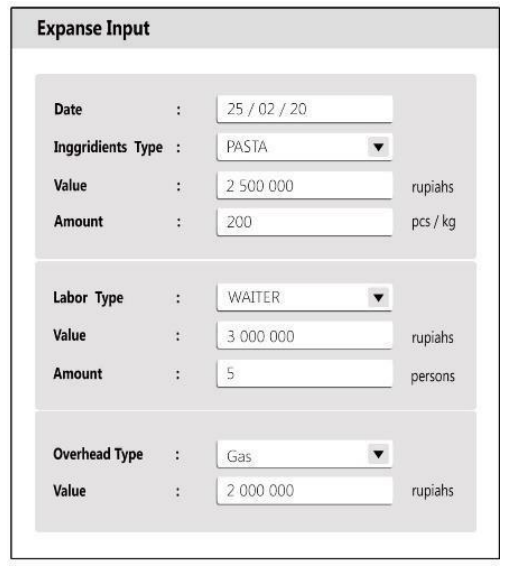

Figure 5 Interface of the Expense input process

\subsubsection{SELLING INPUT}

In this module, we will input food sales data for each

\begin{tabular}{|llll|}
\hline Selling Input & & & \\
& & & \\
Date & $:$ & $26 / 02 / 20$ & \\
Menu Type & $:$ & Aglio Olio & Th \\
Selling Price & $:$ & Rp 50000 & [edit?] \\
Amount & $:$ & 83 & \\
\hline
\end{tabular}

period, both in number and variety.

Figure 6 Interface of the Selling Input process

\subsubsection{THE CATEGORIZING RESULT}

In this module, the process of identifying the level of popularity and profitability of each period will be carried out.

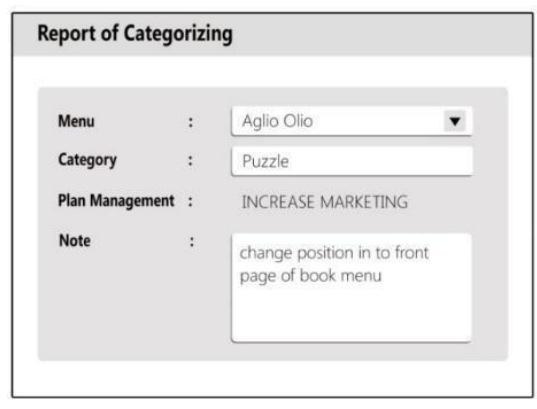

Figure 7 Interface of Result Process

\section{CONCLUSION}

The conclusion of the results obtained from the calculation of popularity rate and margin rate, there are five menus classified as Star, ten menus classified as Plow horse, 13 menus classified as Puzzle and seven menus classified as Dog.

With the analysis of these menus, we can suggest that the start menu can be kept for its performance was good. But the plowhorse menu needs to be more efficient in operational, so the margin will be bigger. On the other hand, the puzzle menus should have a better marketing strategy. And the dog menu should be replaced by another menu since it has little margin and the customer seldom buy it.

\section{REFERENCES}

[1] Widarti, Peni. 2019, Usaha Kuliner Jatim Tumbuh 20\% Tahun Lalu, Tapi Ada Pergeseran Tren, Bisnis.com, viewed 30 Dec 2019, https://surabaya.bisnis.com/read/20190218/532/8 9036 6/usaha-kuliner-jatim-tumbuh-20-tahunlalu-tapi-ada- pergeseran-tren.

[2] Mulyanto, Agus. 2009. Sistem Informasi konsep Dan Aplikasi, Yogyakarta: Pustaka Pelajar

[3] Mulyadi. 2010 Akutansi Biaya, Yogyakarta: Unit Penerbit Dan Percetakan Sekolah Tinggi Ilmu Manajemen YKPN

[4] Kassavana, Michael L. 1999. Computer Systems for Foodservice Operations (A CBI Book). Van Nostrand Reinhold Company 